Georgia State University

ScholarWorks @ Georgia State University

Early Childhood and Elementary Education

Faculty Publications

Early Childhood and Elementary Education

Department

2-1-2017

\title{
Language ideologies in a U.S. state-funded international school: The invisible linguistic repertoires of bilingual refugee students
}

Ana T. Solano-Campos

Georgia State University, asolanocampos@gsu.edu

Follow this and additional works at: https://scholarworks.gsu.edu/ece_facpub

Part of the Pre-Elementary, Early Childhood, Kindergarten Teacher Education Commons

\section{Recommended Citation}

Solano-Campos, Ana T., "Language ideologies in a U.S. state-funded international school: The invisible linguistic repertoires of bilingual refugee students" (2017). Early Childhood and Elementary Education Faculty Publications. 14.

https://scholarworks.gsu.edu/ece_facpub/14

This Article is brought to you for free and open access by the Early Childhood and Elementary Education Department at ScholarWorks @ Georgia State University. It has been accepted for inclusion in Early Childhood and Elementary Education Faculty Publications by an authorized administrator of ScholarWorks @ Georgia State University. For more information, please contact scholarworks@gsu.edu. 


\title{
Author Accepted Manuscript
}

Solano-Campos, A. (2017). Language ideologies in a U.S. state-funded international school: The invisible linguistic repertoires of bilingual refugee students. Journal of Research in International Education, 16(1), 36-54.

\section{Language ideologies in a U.S. state-funded international school: The invisible linguistic repertoire of bilingual refugee students}

\author{
Ana Solano-Campos
}

"If there is one educational setting where bilingualism is valued and nurtured, one would think that it is the international school."

Kanno, 2009

A common assumption about international schools ${ }^{1}$ is that they are private institutions catering to the elites. However, in the last fifteen years there has been an increase of state-funded International Baccalaureate (IB) schools in the United States, many of which serve high numbers of bilingual and multilingual children from low income, immigrant or refugee backgrounds (Bunnell 2009; IB 2012). The IB (2016a) reports that 85 percent of IB schools in the United States — over 1,400 — are state schools, 25 percent of which are Primary Year Programmes (PYP) serving children ages 3-12. Over half of IB state schools across the United States are also

\footnotetext{
${ }^{1}$ Hayden (2006: 8) describes international education as an "umbrella" encompassing various developmental, global, and cosmopolitan orientations to education. In the same way, international schools comprise a heterogeneous grouping of institutions "which may or may not share an underlying educational philosophy" (Hayden \& Thompson, 1995: 332). There are a myriad of categories and groupings of international schools (Hayden, 2006; Carder, 2007), from which the International Baccalaureate (IB) is just one. In this article, I will be referring predominantly to IB schools.
} 
classified as Title I schools (International Baccalaureate, 2012), a designation that refers to schools with at least 40 percent of students from low-income families (National Center for Education Statistics, 2012). In addition, the IB acknowledges that most students in IB schoolsas many as 75 or 80 percent (Sears, 2015) — have "complex multilingual backgrounds" (International Baccalaureate, 2008: 2) and "are constructing knowledge [at school] in a language that is not their mother tongue" (International Baccalaureate, 2008: 1).

Historically, students from immigrant and language minority backgrounds have been underserved in public schools in the United States, where education policy and curriculum have typically sponsored a monoglossic ${ }^{2}$ orientation towards language (García et al., 2012). In contrast, the IB curriculum and language policy intentionally emphasize the value of multilingualism, additional language instruction, and mother tongue maintenance (International Baccalaureate, 2014a), an orientation that sets many international schools apart from typical U.S. public schools. Given this explicit commitment to language diversity, how are the linguistic repertoires of students who have been traditionally marginalized in typical public schools supported in the IB? And, more specifically, what is the nature of the experiences of bilingual and multilingual immigrant/refugee children in IB settings? I investigated these questions by conducting a qualitative case study of a fourth-grade classroom in a state-funded IB PYP school in the United States. First, I provide a review of relevant literature on language policy and student diversity in the IB; followed by an overview of the theoretical framework and methodology of the study. Last, I share findings and discuss implications for policy, practice, and theory.

\section{Linguistic and Cultural Diversity in the IB PYP}

Research on the IB PYP is prolific and spans several areas, including program impact, program development, quality assurance, and assessment, among others (Eaude, 2014). Much of this important research has been conducted or commissioned by the IB Research Department

\footnotetext{
2 An orientation that "assumes that legitimate linguistic practices are only those enacted by monolinguals" (García, 2009a:115).
} 
(International Baccalaureate, 2016; Hemelt, 2015). There are two primary subfields in this literature that are directly related to the research questions that I pose in this study: 1) Research on the treatment of bilingualism in primary IB schools, and 2) research on underrepresented children in the IB PYP. I elaborate on each of these two areas of inquiry in the following sections.

\section{Bilingualism in the IB PYP}

Since its inception, the IB has emphasized the learning of additional languages ${ }^{3}$ as a valuable commodity to gain entry into the global economy and as an important component fulfilling the tenet of international mindedness that is central to the IB philosophy. The IB's "conceptual framework of language and learning" informing additional languages and mother tongue instruction highlights the importance of affirming students' identities and promoting additive bilingualism ${ }^{4}$ (International Baccalaureate 2000, 2008; Eaude 2014). In order to support schools, the IB articulates guidelines encouraging schools to establish a steering committee to write the school's language policy and language profile (International Baccalaureate, 2008, 2011, 2014a) and oversees language additions and language policy/course changes, which are subject to a five-stage review process (International Baccalaureate, 2014a).

\footnotetext{
${ }^{3}$ The learning of additional languages in the PYP starts at age seven (Eaude, 2014), and is nurtured throughout the Middle Years Programme (MYP) and the Diploma Programme, the latter of which has a bilingual option (Sers 2015: 2704). Currently, there are three main groups of languages in the IB PYP: working languages, which include English, Spanish, and French; access languages, which for the PYP are Arabic, Chinese, Indonesian, and Turkish; and languages of instruction, which mostly consist of national (official) languages in the country where schools are located (International Baccalaureate, 2014b). In the PYP ESOL is also considered an additional language (Carder, 2006).

${ }^{4}$ According to Sears (2015: 2453) "bilinguals achieve additive bilingualism when they acquire the spoken and written forms of another language without loss to the maintenance and development of their home language."
} 
Yet, even when the IB's language guidance seems ample, Carder (2006) has reported that the language guidelines for the PYP may not be as comprehensive as those provided for the MYP and Diploma Programs. More recent research on language policies and additional languages in the PYP also voices concerns about the scope and reach of language policies in the IB PYP (Fee et al., 2014; Lebreton, 2014; Van Vooren et al., 2013). This research indicates that whereas the general nature of the IB language policy guidelines proves flexible enough to be adapted to different national and school contexts, it is precisely this flexibility which proves challenging, becoming ambiguous when negotiating the role of language and language instruction/support in superdiverse local contexts. Importantly, in the last decade, scholars have also noted an absence of empirical studies on the IB PYP (Lester \& Lochmiller, 2014; Mills, 2013), and—particularlyon the treatment of bilingualism in primary IB schools (Carder, 2006, 2007; Gallagher: 2008; Lopez, 2010; Murphy, 2003; Sears, 2004; Van Vooren et al., 2013).

In addition, researchers have shown concerns about the risk for subtractive bilingualism ${ }^{5}$ for children in the PYP who do not speak the languages of instruction or the working languages of IB PYPs. Specifically, there is a perception that the IB continues to perpetuate Western and English-dominant epistemologies (van Ord, 2007) through its language requirements (Bartlett, 1994; Buckheit, 1995, McKenzie, 2001). In fact, the IB (2014c) reports that English alone is the main medium of instruction in most IB schools around the world. Even though the number of bilingual IB PYPs in the United States has increased significantly since 2005 (when there were none), only 36 schools, around 8\% of IB World PYPs across the country, were bilingual schools in 2015 (International Baccalaureate Research Office, 2015, personal communication).

\section{The Opening of the IB to Underrepresented Populations}

\footnotetext{
${ }^{5}$ Subtractive bilingualism is "the outcome that occurs when students focus on the school language at the expense of their home language, which may result in their home language remaining underdeveloped and underused" (Sears, 2015: 2461).
} 
Although the implementation of IB programs in state-funded schools in the United States is not a new development (Bunnell, 2009; Lopez, 2010), we know little about how children from low socioeconomic and immigrant/refugee backgrounds fare in the IB PYP. In the last decade, the IB has been intentional about expanding and documenting participation of historically marginalized students in IB schools (Corcoran and Gerry, 2010; Siskin et al., 2010). Yet, this expansion has taken place primarily through projects building and piloting pathways from the Middle Years Programme (MYP) to the Diploma Programme, with little or no reference to the PYP's role in this continuum. When it comes to the MYP and the DP, researchers have noted that recruitment of students in urban low-income school settings is not enough to improve efforts at expanding the IB to historically underrepresented populations (May and Perna, 2011). Indeed, meaningful student retainment and support in those contexts can prove challenging because of difficulties providing appropriate support to teachers, aligning IB and district goals, and expanding teacher beliefs about student readiness (Conner, 2008; Corcoran and Gerry, 2010; Gerry and Corcoran, 2011; May and Perna, 2011; Siskin et al., 2010).

Researchers studying state-funded IB schools in the United States have looked at the experiences of refugee learners (author, 2014; Massoumi, 2009; Quaynor, 2012) and at the implementation of international programs in urban contexts (Lopez, 2010; Mills, 2013), among others $^{6}$. Broadly, this research reveals that "the use of International Baccalaureate programs is no guarantee of a global education connected to the experiences of immigrant and refugee youth" (Quaynor, 2015). Adding to this literature, scholars conducting research outside of the United States have documented how competing global and national discourses hinder the efforts of state international schools to nurture and capitalize on their students' backgrounds (Bates, 2012; Bunnell, 2010; Halicioglu, 2008; Resnik, 2009, 2012; Visser, 2010). Given the significant shift in the socioeconomic and linguistic composition of the student body in the IB PYP, learning more

\footnotetext{
${ }^{6}$ also see May, 2009; García, Flores \& Woodley 2012; Hall et al., 2009; Stillisano et al., 2011; Hartman, 2008; Jordan, 2009; Tan and Bibby, 2010; Twigg, 2010
} 
about how IB language principles can be executed to promote additive bilingualism for all students is a pressing need. It is exactly this area of inquiry, and its implications for students' experiences in the IB that constitutes the focus of this study.

\section{Theoretical Framework}

I approached this study with the understanding that schools are ideological sites (Bartolomé, 2010; Silverstein, 1998) where language can be used to either perpetuate or challenge social inequities. I positioned the classroom where I conducted this study as existing within a linguistic field. Bourdieu (2003: 57) describes linguistic fields as systems of "linguistic relations of power based on the unequal distribution of linguistic capital.” As such, classrooms reflect language ideologies (Woolard and Schieffelin, 1994), or belief systems about language users and their linguistic practices (McGroarty, 2010), which are grounded in power dynamics in the society at large.

To reflect this perspective, I grounded my research on three theoretical premises: (1) language exists within hierarchical social systems shaped by particular histories and beliefs, (2) language is a symbolic good that grants/denies access to various positions and spaces, and (3) language intersects with other social categories and identities. These three premises are informed by poststructuralist bodies of work in the fields of sociolinguistics (Schieffelin et al., 1998; Bourdieu, 2003), critical applied linguistics (Pennycook, 2001, 2004; Phillipson, 1992), and social psychology (Collins, 1991; Creenshaw, 1998). The three-fold conceptual approach of this study provides a frame to understand how cumulative intersectionality (Suárez-Orozco, Yoshikawa, and Tseng, 2015) — the layers of linguistic privilege and oppression that students might experience - interact with the intended, taught, and assessed IB language policy and curriculum. Making these connections is important to create educational spaces that respect and nurture the linguistic human rights (Skutnabb-Kangas and Phillipson, 1995) of all students.

\section{Methodology}


I conducted this qualitative case study in the spring of 2012. This research was part of a larger comparative study of language ideologies and civic practices in culturally and linguistically diverse schools in Costa Rica and the United States (author, 2014). In this article, I refer exclusively to the data and findings related to language ideologies from the case study in the United States.

\section{Fieldsite and Participants}

I conducted fieldwork for this study in the Southern United States, in one of the largest refugee resettlement areas in the country. Because of the unique characteristics of the school, which make it easily identifiable, I made the decision not to disclose its exact location in order to protect the students' and teachers' identities. The state where I conducted the study did not have any laws explicitly restricting bilingual education or use of the students' home languages to facilitate instruction and communication with parents. However, it dictated that Sheltered English, along with English to Speakers of Other Languages (ESOL), was the preferred method of instruction to make content meaningful to emergent bilinguals.

The school, River Song Elementary (RSE; pseudonym), was a charter state-funded IB school implementing the PYP program alongside the education standards required by their district. According to school materials, 50 per cent of the student body was made up of children who were immigrants or refugees and two thirds of the students at RSE lived at or below the poverty level. The students came from around 40 different countries and spoke up to 25 languages. The teachers too were culturally and linguistically diverse, representing almost 30 countries and half as many languages. RSE was unique in that community members created the school specifically to support the needs of refugee children.

After volunteering at RSE for over one year, I approached the school principal about conducting the study in a fourth grade classroom. I purposefully selected fourth grade students because they are at a crucial age in which their cognitive, linguistic, social, and global awareness expand in important ways (Barrett and Oppenheimer, 2011; Corsaro, 2012; Huston and Ripke, 
2006; Paradis et al., 2010). The principal nominated Mr. Williams (pseudonym) who agreed to participate in the study, along with twelve of his students. Collectively, the students represented seven national contexts - the United States, Myanmar, Iraqi Kurdistan, Somalia, Sierra Leone, Senegal, and Russia — and spoke 14 languages at varying levels of proficiency — Arabic, Burmese, Chin, English, Kurdish, Hindi, Myanmar, Spanish, Somali, Swahili, Mande, Krio, Wolof, and Russian (see Table 1).

Table 1. Participating Students

\begin{tabular}{lllll}
\hline$\#$ & Student & National Background & Students' Language/s & $\begin{array}{l}\text { Foreign Language } \\
\text { Choice at School** }\end{array}$ \\
\hline $\mathbf{1}$ & Ahn & Myanmar** & Myanmar, Chin, English & ESOL \\
$\mathbf{2}$ & Helima & Iraqi Kurdistan*** & English, Kurdish, Arabic & ESOL \\
$\mathbf{3}$ & Ameerah & Somalia & English, Somali, Hindi & French \\
$\mathbf{4}$ & Ahmed & Somalia & English, Swahili, Somali & Spanish \\
$\mathbf{5}$ & Khari & Sierra Leone & English, Krio, Mande & French \\
$\mathbf{6}$ & Izza & Senegal & English, Wolof & French \\
$\mathbf{8}$ & Emma & The United States & English, Spanish & Spanish \\
$\mathbf{9}$ & David & The United States & English, Spanish & Spanish \\
$\mathbf{7}$ & April & The United States & English, French, Spanish & French \\
$\mathbf{1 0}$ & Irina & Russia & English, Russian & Spanish \\
$\mathbf{1 1}$ & John & The United States & English, Spanish & Spanish \\
$\mathbf{1 2}$ & Latisha & The United States & English, French, Spanish & French \\
\hline
\end{tabular}

* The language of instruction at RSE was English and students were required to learn one of two additional languages - French or Spanish — taught daily for an hour and forty-five minutes at the end of the day. Newcomer children or emergent bilingual children were required to take ESOL rather than a foreign language. At the time of my research, the school did not have any language maintenance or mother tongue programs for students .

**Myanmar was formerly named Burma. Ahn indicated a preference for the name Burma and identified as Burmese.

***Kurdistan is a geo-cultural region including portions of Turkey, Iraq, Iran, Armenia and Syria. Iraqi Kurdistan, where Helima was from, is considered an autonomous region of Iraq that has its own self-governing body and constitution. Kurdish people in Iraq have a distinct national identity based on their Kurdish culture, religion, and language.

\section{Data Sources}

Fieldwork consisted of document analysis, ethnographic observations, interviews, and focus groups with students. I looked at relevant printed and online documents and artifacts, such 
as the IB PYP curriculum, the RSE curriculum, the state's curriculum for fourth grade, the RSE website, and hard copies of artifacts provided during classroom and school events. I was at the school three times a week over a period of twelve weeks, for an average of twelve hours per week that resulted in 144 hours of fieldwork. As a participant observer, I observed the children interacting in a range of contexts, during class time, in recess and lunch. I also interacted with the children and their teachers, conversing with them and assisting them when the occasion arose. I wrote fieldnotes and memos of my visits to Mr. Williams' class, including all naturally occurring teacher and student discourse.

For the focus groups, I presented children with a fictional character who had some questions about the United States. The focus group protocol prompted children to discuss possible scenarios. For example, what language would the fictional character speak? Should it speak English or its home language, or both? Who decides what language it learns? During the individual interviews, I asked the children more personal questions, such as, how many languages do you speak? Do your parents/classmates speak a language other than English? What language do you speak at school? What language do your classmates speak at school? How do you feel about that? The focus groups and interviews took place in nearby classrooms and play areas that were not in use at the time. I recorded and transcribed the children's responses. I also completed contact summary forms and reflective memos for each recording.

\section{Data Analysis}

For the analysis (see Figure 1), I used Constructivist Grounded Theory (Charmaz, 2006). I exported the documents, fieldnotes, interview transcripts, and focus group transcripts to the qualitative data analysis software MAXQDA. First, I read the documents and transcripts carefully to identify the main practices, situated meanings, and discourses reflected in each text. Then, I assigned codes to each segment of meaning and — via constant comparison among the codes-I refined them and developed categories. Through further revision and comparison of the 
categories, and by recording my observations and analysis in written memos, I identified themes that coincided across data sources (see data triangulation information on Table 2).

Figure 1. Data Analysis Process

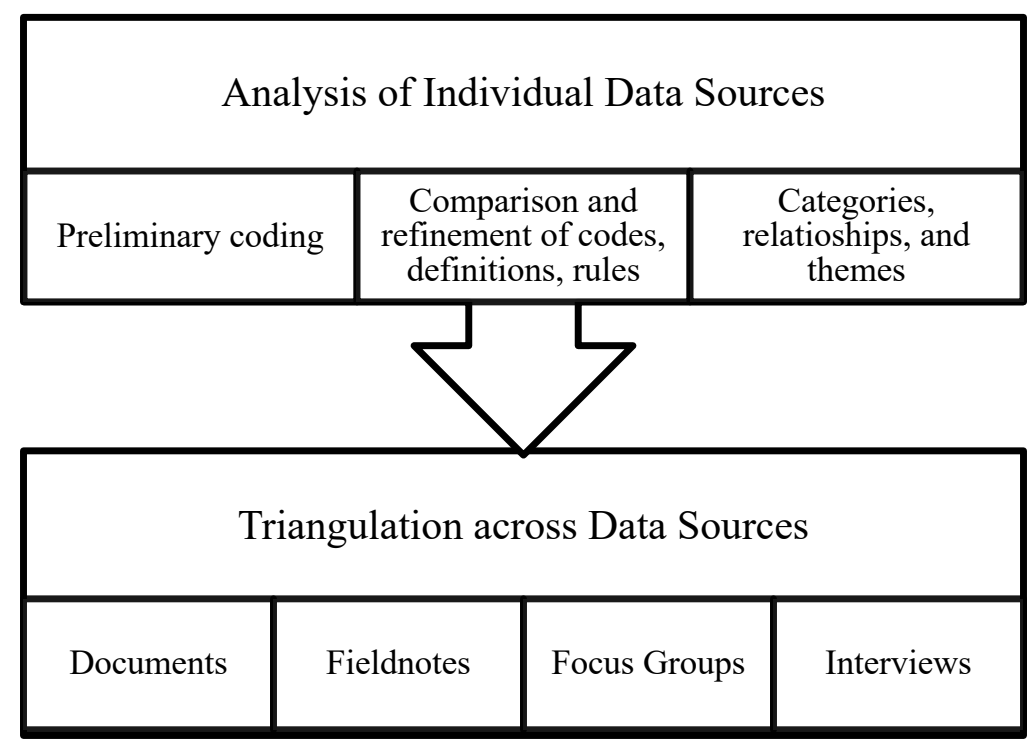

\section{Positionality and Terminology}

This study was informed by my own journey navigating transnational and linguistically diverse landscapes. I am a Spanish-English bilingual and first generation immigrant from Latin America who has experienced both being a learner and an educator in superdiverse, plurilingual and urban contexts. The terminology that I use throughout the article acknowledges the complexity of language identities and practices, and affirms the linguistic repertoire of immigrant and refugee students.

\section{Table 2. Triangulation}




\begin{tabular}{llcc}
\hline Data & Linguistic & Linguistic & Linguistic \\
Source/Category & Tokenism & Subordination & Compartmentalization
\end{tabular}

\begin{tabular}{lccc}
\hline Fieldnotes & 28 & 8 & 7 \\
\hline Focus Groups & 12 & 20 & 2 \\
\hline Interviews & 29 & 2 & 37 \\
\hline Documents & 10 & 8 & 1 \\
\hline
\end{tabular}

Note. The numbers represent the coded segments of text for each category.

\section{Linguistic Differentiation in Superdiverse Settings}

Sears (2015: 2507) eloquently states, "subtractive experiences can happen in international schools too." This was the case at RSE, where the ability to speak two or more languages was positioned as linguistic capital, but where the linguistic repertoires of bilingual refugee students were made invisible. In this section, I describe the linguistic landscape at RSE and elaborate on the three processes that contributed to the invisibilization of students' linguistic assets. After that, I discuss the findings and outline future directions for theory, research, policy, and practice.

\section{The Linguistic Landscape at RSE}

It is a sunny day, and teachers, parents, administrators and students have gathered to celebrate the diversity of the student body at RSE. The event starts with a colorful parade, where students wearing traditional outfits representing their countries of origin walk side by side around the neighborhood. The parade culminates in a community auditorium close by, where several dance and music performances featuring the children's many cultural backgrounds take place. Included in the program are three songs representing each of the additional language classes taught at RSE: French, Spanish, and ESOL. The French and Spanish classes sing a translation of the same song, a medley of catchy tunes that is briefly listed in the program. Conversely, the ESOL students sing an adaptation of Woody Guthrie's celebrated tune "This Land is Your Land", , featured prominently on the last page of the program. This particular

\footnotetext{
7 "This Land is Your Land" is a renowned folk song recorded in the 1940s and dubbed by some as "an alternative national anthem" (Spitzer, 2012) for people in the United States. Margolis (2012) describes the
} 
version of the song includes many of the countries of origin of the students at RSE and describes the journeys of refugee children enrolled at the school, many of whom fled their homelands because of war or prosecution. "This land was made for you and me," the children sing in English.

This brief snapshot reflects the palpable global, multicultural, and multilingual ethos of RSE. However, it also unveils processes of linguistic differentiation by which the linguistic repertoires of emergent bilingual refugee students were obscured at school, whereas the bilingualism of their English proficient peers was celebrated. This invisibilization of students' linguistic backgrounds is an example of what Irvine and Gal (2000) call erasure. Erasure is a semiotic process by which "an ideology simplifies a sociolinguistic field, forcing attention on only one part or dimension of it, thereby rendering some linguistic forms or groups invisible or recasting the image of their presence and practices to better fit the ideology" (Gal, 1998: 328).

At RSE bilingualism was valued over monolingualism, but elite bilingualism (Hamel, 2008; Hélot and de Mejía, 2008; García, 2006: 236) emphasizing proficiency in dominant, colonial languages by English proficient speakers, was valued over refugee students' mother tongue bilingualism. RSE's covert language policy solidified this rendering invisible of students' home languages. Three processes, specifically, contributed to perpetuate this language ideology and the subsequent invisibilization of students' linguistic repertoires: linguistic tokenism, linguistic subordination, and linguistic compartmentalization. In the following sections, I describe and illustrate these three processes.

\section{Linguistic Tokenism}

During my fieldwork, I observed practices that reflected the concept of tokenism, occasions in which diversity receives perfunctory attention to convey the illusion of inclusion. Motha (2014: 104-105) describes linguistic tokenism as the act of "purporting to support the

\footnotetext{
song as "an eloquent description of [the United States] beauty and, as originally written, an expression of
} scorn for those who don't see fit to share it." 
development of multilingualism and multiculturalism when it actually surreptitiously suppresses a variety of... cultures [and in this case languages] by falsely implying that they are represented." The problem with linguistic tokenism is that it hides linguistic subordination and exclusion under the mirage of linguistic representation.

The following three examples illustrate how linguistic tokenism was performed at RSE: (1) During my second week at RSE, Mr. Williams, a monolingual English speaker, proudly asked the children to tell me about the languages that they spoke. All participating children-even local children - proudly identified themselves as speakers of two or more languages regardless of their level of proficiency in the language ${ }^{8}$. This was the only time during my fieldwork that students' languages were positioned in a place of relevance during class time in their homeroom ${ }^{9}$. (2) Another day, Ms. Delic_-who was Mr. Williams' paraprofessional and who was originally from Eastern Europe and spoke several languages, among them Bosnian, Serbian, Croatian, and English - used Bosnian in her interactions with students. This was the first and last time that I witnessed the use of a language other than English by a teacher who was not the Spanish or French teacher. (3) After a couple of weeks, I noticed that Mr. Williams wrote the date on the board everyday in three languages: English first, followed by French and then Spanish. None of the children's home languages were used to write the date during my time there.

Although initially resembling a form of "symboling"10 (Gay, 2010: 41), the three examples illustrate the assumption that linguistic representation on its own fulfills the school's commitment to linguistic inclusion. On the contrary, during my time there, none of the participating students' home languages were represented in classroom materials or visuals, in the

\footnotetext{
${ }^{8}$ Whereas refugee children or children of refugees did not include the foreign languages they were learning at school as languages they spoke, the local children did.

${ }^{9}$ In elementary school, a homeroom is a classroom where all students receive instruction together, in the content areas, except for special subjects such as music, arts, and physical education.

${ }^{10}$ Symboling refers to visual imagery and symbols that convey particular meanings. Symboling that reflects and provides healthy messages about students' linguistic identities can be a powerful and positive influence in their learning experiences.
} 
language options offered at River Song Elementary, or in the afterschool programming. As Fee et al. (2014: 53) found in their study of language policies in IB World schools, in many IB schools "mother tongue is brought into the learning environment [only] at the discretion of the teacher." This was also the case at RSE.

\section{Linguistic Subordination}

Even in a context like RSE, which was intentional about creating an ethos of respect and interest in linguistic diversity, refugee students and students of refugee backgrounds had experiences of linguistic subordination. At RSE, students were not explicitly or officially "forbidden" to use their home languages at school, but there was an implicit understanding that this was not an accepted social practice. Khari, for instance, shared, "Well, some people are afraid to speak their language at school because they think someone might laugh at them."

There were two elements that promoted students' linguistic subordination at RSE: English as a medium of instruction and ESOL-first requirements. RSE's focus on English was a deliberate programmatic choice reflecting the English-dominant philosophy that is pervasive across many typical international and state schools. Certainly, the development of English proficiency is important for students in the United States to participate in society and contribute to their communities. However, emphasis on English becomes problematic when it presupposes a double subordination (Macedo and Bartolomé 2001: 37) that perpetuates students' simultaneous experiences of language loss and linguistic inadequacy.

Although RSE had systems of support for emergent bilingual students in the form of pullout ESOL instruction, the ESOL program did not support children's bilingualism, but their socialization and eventual assimilation into English. The school website described RSE as a multilingual heaven, yet explained that emergent bilingual students had to go through a "rigorous" ESOL program before joining their classmates in learning an additional language, stressing the importance of learning English to claim membership into the school and national community. In these statements, emergent bilingual children were turned, albeit rhetorically, into 
individuals in the process of becoming American and in need of support to transition to Americanness, seemingly contradicting the school's focus on global citizenship.

\section{Linguistic Compartmentalization}

The invisibilization of children's languages through linguistic tokenism and linguistic subordination concealed a linguistic duality in which students' languages embodied the "unofficial" domain of the home, and English resided in the "official" space of the school (Sears 2015:2341). This compartmentalization is reminiscent of Fischman's concept of societal diglossia, or "the functional distribution of two languages" (García, 2009a: 75). The most relevant aspect of this finding is that students reported different degrees of concern and struggle with this linguistic duality. For example, although all participating children reported an "us-them" linguistic dichotomy, the nuances of this dichotomy, presented below, were different according to the background of the student.

Language ownership. Refugee children and children of refugees varied in their expressions of language ownership. Whereas refugee children qualified English against their home language(s) using possessive nouns to underscore ownership, children of refugees used comparative structures. For instance, in a conversation during lunch, Ahn referred to Chin as "my language" and "my words" and connected it with social groups like "my family" and "my people," indicating a strong feeling of ownership and identification with Chin, while discursively distancing herself from English. In contrast, when I asked Khari what languages she spoke, she used linguistic structures that positioned her linguistic systems within competing social and academic spaces, sharing, "[I speak] Three [languages]... English, Creole, and Mandei...At school I speak English” (Interview, 03/07/2012: 24-33).

Language loss. Refugee children and children of refugees spoke about the tensions of growing up with emergent bilingual parents. Refugee children reported experiences of linguistic maintenance and mediation at home. Helima - for example - explained, 
[It's] Hard because sometimes I talk with my mom, and I speak Kurdish when I just stepped in the house. I can't speak English because every time, because my mom doesn't know English, she doesn't know what are we saying. Some she knows. [She feels] sad because she doesn't know how we, how do we talk and then she doesn't talk about that, [that] people are talking about her, maybe she doesn't know what people are talking about. We don't talk about her. We talk about funny stuff in my house. I am sad because I wish my whole family gets a good life and my mom gets good English. I am going to teach her one day. (Interview: 7-3).

Helima candidly empathized with her mother's struggle of being positioned as a linguistic other or outsider. In addition, she deployed the narrative of the native speaker fallacy when she makes a direct link between "good English" and a "good life." Helima envisioned herself as the main actor in fulfilling the hopes that she has for her family, by mediating her English and Kurdish worlds. In contrast, Izza shared, "I speak Wolof to my mom, but sometimes I speak English and she speaks Wolof to me, and I can't really understand [Wolof]..." (Interview, 3/07/2012: 25). Unlike Helima, Izza focused not on linguistic maintenance or mediation, but on loss. She pointed to her own process of subtractive bilingualism and to losing the linguistic connection that she had with her mother.

Language use. Refugee children were the only ones to report using their home languages at school with children in other classrooms or grade-levels, often cousins or relatives who also attended the school. For instance, Helima talked about how her cousins allowed her to mediate her school experience using Kurdish. She told me,

Uhm, sometimes when I came to RSE, I never speak English, and then at least my cousin were here before me, and then I just speak with them, and they said: uhm, my name, like that. I told them in Kurdish because I didn't know in English.

Ahn also explained, 
Sometimes my friend in the other classroom speak[s] Myanmar because we speak together, other times... You know Lily in the other class? She, uhm, she is like from me, because she speaks the same language, and I speak the same language as her, we both speak Burmese.

In both instances, Ahn and Helima referred to their home languages positively, as assets and tools. They highlighted how relationships with other speakers of those languages supported them in their transition to an English-medium school. They also illustrated the process of circumventing the dominance of English in their homeroom by operating outside of their classroom and at the margins of academic spaces. Izza, for instance, mentioned the practice of looking outside of the school to stay connected with her linguistic background. She shared, "[Khari's] mother knows how to speak Wolof, so I speak Wolof with her a little bit... It feels nice to speak with someone that has the same language than me (Interview, 03/07/2012: 49).

Language choice. Children of refugees did not mention using a language other than English at school. However, they referred to instances of linguistic choice and agency. For example, Khari explained, "Well, it's hard that most of the people here are not really from another country. They were like born here, but their parents are from a different country; so, they go with their parents' country..." (Interview, 03/07/2012: 83). In this statement, Khari communicates the intentional choice that many children of refugees make to stay connected to their parents' countries of origin — and inherently languages — of origin, even when that connection is hindered by dominant linguistic hierarchies. In her comment, Khari illuminates the type of decision-making that second generation immigrants in general—and in this case children of refugees in particular - are faced with, as well as the type of choices they make in regard to their national and linguistic backgrounds.

Language (ab)normalization. Children who identified as local also referred to the school-home duality, qualifying linguistic diversity and bilingualism as "special" and monolingualism as "average.” For example, April explained that immigrants often maintain 
"their" language in order to stay connected to "their" family, but stressed that English was essential to speak to "us" (Focus Group 3, 03/15/2012: 199). April also mentioned that a person could be bilingual "if you want to be special." Echoing April's comment, Emma described monolingualism as "normal" and "average" (Interview, 03/16/2012: 44-47). Importantly, in describing Matsuda \& Duran's (2013) work, Motha (2014: 54) explains that “if English monolingualism becomes understood to be 'American,' then multilingualism, particularly multilingualism that is not anchored by nativeness in English, becomes un-American." Both April and Emma's comments normalized English, simultaneously exoticizing and abnormalizing bilingualism. In their remarks, as the special character of bilingualism was highlighted, its quality as mainstream was neglected.

\section{Discussion and Recommendations}

Norton (2010: 361) states that "responding to diversity in the language classroom requires an imaginative assessment of what is possible as well as a critical assessment of what is desirable." Several researchers studying the educational access and opportunities of dual language learners in IB PYPs have established what is desirable: contexts that affirm and support additive bilingualism for all learners, not only for elective bilinguals. Yet, we are left with the question of how to make this possible in super-diverse IB PYP classrooms like the one at RSE. Based on my findings, I offer three potential directions to address this question.

\section{Direction 1: A Longview of Students' Language Ideology Development in the IB}

In this study, I looked at language instruction in a state-funded international school. My findings only reflect the experiences of the participating children in the specific context of RSE, an English-medium IB PYP school, during that particular time period. However, language-related practices and beliefs vary across and within learners across time (Kroskrity 2004; McGroarty 2010). Thus, it is important to think about students' journeys in the IB PYP. In what ways do their language experiences and beliefs evolve over time? What elements contribute to that evolution? In what ways are students' journeys similar or different? 
During the time that I spent at RSE, I found concrete ways in which the linguistic experiences of students were markedly different depending on their immigrant backgrounds. However, existing research has often neglected these differences. In this regard, Suárez-Orozco and Suárez-Orozco (2008: 4) have stressed that "while there are similarities between the experiences of immigrants and those of the second generation, their realities are distinct and must be separately understood." The same can be said of the experiences of refugee children and children of refugees - in comparison to that of local children. Based on this, a potential area of research in the IB PYP is to determine whether students' experiences with longer trajectories in state-funded IB schools also reflect the types of linguistic differentiation that I identified in this study.

\section{Direction 2: An Expansion of IB's Language Guidance and Teacher Preparation}

As a child-centered study, this research emphasized children's experiences rather than those of educators or administrators. As my data gathering and analysis unfolded, it became clear that RSE's curricular and instructional design did not necessarily address the linguistic challenges that the participating students' encountered at school. However, from my study design, I was not able to determine the factors that drove the decision-making of the administration and faculty at RSE in regard to school language policies, curriculum, and instruction. What I was able to ascertain is that there were several missing opportunities to promote additive bilingualism across the school and in the classroom where this study took place.

RSE's covert language policy—which aligned with both state/district preferences and the English-dominant nature of the IB - directed teachers' efforts to "sheltering" English instruction, rather than to nurturing bilingualism. In this regard, IB PYP schools could benefit from having official resources from the IB to navigate dissonances between state and IB goals, and more importantly, guidelines to create bilingual PYPs that address the linguistic needs of all students. In fact, Fee et al. (2014: 126) reported that although the IB language policy was useful to teachers and administrators, "the document at times was not written in a way that was accessible for a 
general school audience or for parents." In fact, interviewees pointed out that there is a need for the dissemination of "case studies of how other [in this case bilingual PYP] schools have approached language policy, examples of other written language policy documents, and examples of how other schools have put their written policies into practice" (for an example of a case study see Scott, 2011).

Teacher training and support is also particularly needed to ensure that educators are prepared to execute linguistically sustaining practices and to avoid teaching "a form of literacy that gives learners a lasting experience of subordination" (Macedo and Bartolomé, 2000: 21). From my conversations with faculty, I knew that teachers at RSE were caring educators committed to providing their students with a safe school environment. However, to date, it is not clear to what extent teachers and administrators across the IB are being prepared to effectively reach linguistically diverse student populations (Levy, 2007).

\section{Direction 3: The Enrichment of Curriculum and Instruction}

For Murphy (2003a: 37) the provision of mother tongue support "should be a stated goal of every international school," and programs should modify the structure of their curriculum if they are not already addressing this important goal. One the biggest challenges that RSE facedas do many international schools around the world - is the multilingual composition of its student body. Whereas one-way and two-way bilingual education programs have the potential to succeed in binational, bilingual/bicultural settings, international schools often benefit most from programs that can reach student populations with greater linguistic diversity. In these contexts, language models that are grounded on philosophies of dynamic plurilingualism—such as multiple multilingual education (García, 2009b) and enriched language education (Carder, 2007) — are the most likely to be successful.

For García (2009b: 149), “multiple multilingual programs mix and blend types of bilingual education programs as they see fit, and develop academic language use in one or more languages." An instance of this is Carder's (2007) three-program model for enriching language 
education in international schools, which includes a second language program, a mother tongue program, and a professional development component for faculty and staff. Using Thomas and Collier's (1997:42) Prism model, Carder (2007) suggests implementing ESL and mother tongue programs as "twin" or "joint" programs under an "ESL and Mother Tongue Department" (Carder 2007: 935) where (1) all emergent bilingual learners take both classes, (2) all mother tongues are represented in the programming, and (3) home room teachers use cross-linguistic strategies to elevate the status of students' home languages in mainstream classrooms.

Number of additional languages, time, and length of instruction for each student would depend on the particular needs and resources of each school, but Carder (2007:1110) emphasizes that "the focus should be on literacy in the mother tongue and proficiency in the language of instruction, over and above learning another language."

While acknowledging the logistical and recruitment challenges of this model, Carder points to the importance of family and community engagement to fulfill the language needs of students. As in RSE, families and communities are often underutilized linguistic assets that can make powerful contributions to IB PYP schools via language awareness and maintenance initiatives (Hélot \& Young, 2010). Their purposeful integration into the school life has the potential to shift the power dynamics that continue to uphold linguistic hierarchies, particularly if schools provide parents with the information they need to advocate for linguistically relevant teaching for their children ${ }^{11}$.

\section{CONCLUSION}

In this study, I documented language ideologies at River Song Elementary (RSE), a statefunded IB PYP school where English was the medium of instruction. I found that, even when RSE positioned bilingualism as linguistic capital, the linguistic repertoires of bilingual refugee students were invisibilized through the processes of linguistic tokenism, linguistic subordination,

\footnotetext{
11 For instance, Murphy (2003a: 38) recommends that parents should be informed of "the pitfalls their children would face if their mother tongue was not given at least equal time in the school day with English."
} 
and linguistic compartmentalization. These processes of invisibilization are not unique to RSE or to international schools. Yet it is precisely this, the fact that an international curricula does not prove immune to the pervasive nature of subtractive bilingualism, that underscores the urgency to address these issues.

The opening of the IB to underrepresented populations takes place in the midst of competing and related processes of globalization, westernization, and nationalism (Bunnell, 2012; Drake, 2004; Frey and Whitehead, 2009; Lauder, 2007; Parker, 2011; Resnik, 2012; van Ord, 2007). In theory, access to an international education provides typically marginalized students with opportunities to obtain educational credentials and create networks that will place them in an advantageous position to compete in what Lauder (2007: 445) calls the global "war for talent." Yet, I argue that in doing that international schools may be constructing vulnerable populations of students as recipients of linguistic dispositions and skills that they might already possess, but that are not considered linguistic capital for the global economy.

In educating immigrant and refugee bilingual or multilingual children, IB PYP schools face an ethical dilemma: Can they do so without inducing their students, "the holders of dominated linguistic competence to collaborate in the destruction of their instruments of expression... with the more or less explicit intention of increasing their value on the educational market"? (Bourdieu, 2003: 49). UNESCO's Universal Declaration on Linguistic Rights asserts that members of a language group, including those individuals established in another language community, such as immigrants and refugees, have "the right for their own language and culture to be taught" (p. 5). Although this is an issue that is relevant and pressing in all school settings, it becomes particularly urgent in the IB because of its already intentional institutional support for home language maintenance: What does it mean when an organization that values and supports bilingualism is not able to ensure opportunities for all students to access and develop additive bilingualism? What lessons can we learn from IB PYP schools about overcoming the challenges to educate bilingual and multilingual students? 


\section{REFERENCES}

Barrett M and Oppenheimer L (2011) Findings, theories and methods in the study of children's national identifications and national attitudes. European Journal of Developmental Psychology 8(1): 5-24. doi:10.1080/17405629.2010.533955

Bartolomé L (2010) Daring to infuse ideology into language-teacher education. In: May S and Sleeter C (eds) Critical multiculturalism: Theory and praxis. New York: Routledge, pp. 47-59.

Bates R (2012) Is global citizenship possible, and can international schools provide it? Journal of Research in International Education, 11(3): 262-274. doi: $10.1177 / 1475240912461884$

Bourdieu P (2003) $\left(7^{\text {th }}\right.$ ed) Language and symbolic power. Cambridge, MA: Harvard Press.

Bunnell T (2010) The momentum behind the International Primary Curriculum in schools in England. Journal of Curriculum Studies 42(4): 471-486. doi:10.1080/00220272.2010.487315

Bunnell T (2009) The International Baccalaureate in the USA and the emerging 'culture war'. Discourse: Studies in the Cultural Politics of Education 30(1): 61-72. doi: $10.1080 / 01596300802643090$

Bunnell T (2012) Global education under attack: International Baccalaureate in America. Frankfurt am Main, DEU: Peter Lang AG.

Carder M (2006) Bilingualism in International Baccalaureate Programmes, with particular reference to international schools. Journal of Research in International Education, 5(1): 105-122.

Carder M (2007) Bilingualism in International schools: A model for enriching 
language education. Tonawanda, NY: Multilingual Matters.

Charmaz K (2006) Constructing grounded theory: A practical guide through

qualitative analysis. Thousand Oaks, CA: Sage.

Conner J (2008) From international schools to inner-city schools: The first principles of the International Baccalaureate Diploma Program. Teachers College Record, 110(2): 322-351.

Corcoran TB and Gerry GB (2010) Expanding Access, Participation, and Success in International Baccalaureate Programmes: Year 1 Documentation Report. Consortium for Policy Research in Education.

Collins H (1991) Black feminist thought: Knowledge, consciousness and the politics of empowerment. New York: Routledge.

Corsaro W (2011) The sociology of childhood. Thousand Oaks, CA: SAGE.

Crenshaw K (1989) Demarginalizing the Intersection of Race and Sex: A Black Feminist Critique of Antidiscrimination Doctrine, Feminist Theory and Antiracist Politics. University of Chicago Legal Forum: 139-67.

Drake B (2004) International education and IB programmes: Worldwide expansion and potential cultural dissonances. Journal of Research in International Education, 3: 189205.

Eaude T (2014) Primary education: A literature review. Report to the International Baccalaureate Organization. Retrieved from http://www.ibo.org/globalassets/ publications/ib-research/primaryeducationaliteraturereview.pdf

Fee M, Liu N, Duggan J, Arias B and Wiley T (2014) Investigating language policies in IB World schools. DC: Center for Applied Linguistics. Retrieved from http://ibo.org/globalassets/publications/ib-research/languagepolicyfullreport.pdf

Fishman, J. (1977). The social science perspective. In Center for Applied Linguistics (Ed.), Bilingual education: Current perspectives. Arlington, VA: CAL. 
Frey CJ and Whitehead D (2009) International education policies and the boundaries of global citizenship in the US. Journal of Curriculum Studies, 41(2): 269-290. doi:10.1080/00220270802509730

Gal S (1998) Language ideologies. In Schieffelin B, Woolard K, and Kroskrity P (eds.) Language ideologies: Practice and theory. New York: Oxford University Press, pp. 317332.

Gallagher E (2008) Equal rights to the curriculum: Many languages, one message. Bristol: Multilingual Matters.

García O (2006) Lost in transculturation: The case of bilingual education in New York City. In Putz M, Fishman JA, and Van Aertselaer N (eds.) Along the Routes to Power: Exploration of the empowerment through language Berlin:

Mouton de Gruyter, pp. 157-178. Retrieved from http://ofeliagarciadotorg.files.wordpress.com/ 2011/02/lost-in-transculturation.pdf

García O (2009a) Bilingual education in the 21st century: A global perspective.

Malden, MA: Wiley/Blackwell.

García O (2009b) Education, multilingualism and translanguaging in the 21st century.

In Mohanty A, Panda M, Phillipson R and Skutnabb-Kangas T (eds) Multilingual education for social justice: Globalising the local. New Delhi: Orient Blackswan, pp. 128-145. Retrieved from https://ofeliagarciadotorg.files. wordpress.com/2011/02/education-multilingualism-translanguaging-21st-century.pdf García O, Flores N and Woodley H (2012) Transgressing monolingualism and bilingual dualities: Translanguaging pedagogies. In Yiakoumetti A (ed) Harnessing linguistic variation to improve education. Bern: Peter Lang, pp. 45-75 Retrieved from http://ofeliagarciadotorg.files.wordpress.com/2011/02/ surbaneduca120920150401.pdf Gay G (2010) Culturally responsive teaching: Theory, research, and practice. NY: Teachers College Press. 
Gerry G and Corcoran T (2011) Expanding access, participation, and success in International Baccalaureate Programmes (IB access project): Evaluation report year two. Consortium for Policy Research in Education.

Halicioglu M (2008) The IB Diploma Programme in national schools: The case of Turkey. Journal of Research in International Education, 7(2): 164-183.

Hall J, Elder T, Thompson J and Pollack S (2009) IBNA: The Primary Years

Programme field study. Athens, Georgia: University of Georgia Education Policy and Evaluation Center.

Hartman J (2008) A descriptive study of characteristics and practices of International Baccalaureate elementary principals as perceived by principals, coordinators, and teachers. PhD Thesis. Retrieved from ProQuest Dissertations and Theses database. (3338003)

Hayden M C (2006) Introduction to international education. Thousand Oaks, CA: Sage.

Hemelt SW (2015) The impact of the International Baccalaureate's Primary Years Programme on student performance: Evidence from Michigan and North Carolina. Bethesda, MD: International Baccalaureate Organization.

Hélot C and Young C (2010) Language awareness and/or language learning in French primary schools today. Language Awareness, 3-4: 234-246.

doi: $10.1080 / 09658410308667079$

Huston A and Ripke M (2010) Developmental contexts in middle childhood: Bridges to adolescence and adulthood. NY: Cambridge University Press.

International Baccalaureate (2000) Primary Years Programme: Making the PYP Happen. Geneva, Switzerland: International Baccalaureate. Retrieved from http://www.itari.in/categories/PYP/IBOPYP.pdf 
International Baccalaureate (2008) Learning in a language other than mother tongue in IB programmes. Wales, UK. Retrieved from http://www.asd.edu.qa/uploaded/ about/PDF files/Lang_other than mother tongue.pdf

International Baccalaureate (2011) Language and learning in IB programmes.

Retrieved from https://msturnerealforum.wikispaces.com/file/view/Language andlearninginIBprogrammes.pdf

International Baccalaureate (2012) Research brief: Title I IB schools (2009-2010). Retrieved from http://www.ibo.org/iba/documents/ib global research.pdf

International Baccalaureate (2014a) Language Policy: Information on the International Baccalaureate's support for languages, language courses and languages of instruction. Retrieved from http://www.ibo.org/globalassets/ib-language-policy-en.pdf

International Baccalaureate (2014b) Current IB Languages Table. Retrieved from http://www.ibo.org/globalassets/ib-language-support-levels-en.pdf

International Baccalaureate (2014c) United States. A dynamic presence: Growth and characteristics of IB World schools. Retrieved from https://www.dcds.edu/ uploaded/Buzz/December_2014/UnitedStatesCountryProfile.pdf

International Baccalaureate (2016a) United States. Retrieved from http://www.ibo.org/en/country/US/

International Baccalaureate (2016b) Research. Retrieved from http://www.ibo.org/research/

Irvine JT and Gal S (2000) Language ideology and linguistic differentiation. In:

Kroskrity PV (ed) Regimes of language: Ideologies, polities, and identities. Santa Fe: School of American Research Press, pp. 35-84. Retrieved from http://web.stanford.edu/ eckert/PDF/IrvineGal2000.pdf 
Jordan F (2009) The impact of the Primary Years Program of the International

Baccalaureate Organization on the English language arts test scores of third, fourth, and fifth grade students in South Carolina. (Doctor of Education Dissertation), Retrieved from, ProQuest Dissertations and Theses database. (3421368).

Kanno Y (2009) Review of Bilingualism in international schools: a model for enriching language education. International Journal of Bilingual Education and Bilingualism, 12(2): 243-246. doi: 10.1080/13670050802149366

Kroskrity P (2004) Language ideologies. In Duranti A (ed.). A companion to linguistic anthropology. Malden, MA: Blackwell, pp. 496-517.

Lauder H (2007) International schools, education and globalization: Towards a research agenda. In Hayden M, Thompson J and Levy J (eds). The Sage handbook of research in international education. Thousand Oaks, CA: SAGE, pp. 444-461.

Lebreton M (2014) Additional language teaching within the International Baccalaureate Primary Years Programme: A comparative study. Journal of Research in International Education, 13(1): 3-18. doi:10.1177/1475240914521346

Lester N and Lochmiller C (2014) A mixed method case study of International Baccalaureate Primary Year Programmes in four Colombian schools. Indiana, PA: Center for Evaluation and Education Policy. Retrieved from http://ibo.org/globalassets/publications/ib-research/pyp/pyp-columbia-full-report.pdf

Levy J (2007) Pre-service teacher preparation for international settings. In: Hayden M, Levy J and Thompson J (eds) The SAGE handbook of research in international education. London: SAGE Publications, pp. 212-223. doi:10.4135/9781848607866.n19

Lopez SM (2010) Internationalizing education: A study of the impact of implementing an international program on an urban elementary school. PhD Thesis, University of Southern California. ProQuest Dissertations and Theses. 
Macedo D and Bartolomé L (2001) Dancing with bigotry: Beyond the politics of tolerance. NY: Palgrave.

Margolis L (2012) Behind the song: "This Land is Your Land.” Retrieved from http://americansongwriter.com/2012/06/behind-the-song-this-land-is-yourland/

Massoumi N (2009) Seeking refuge in urban america: Refugee students in an international public high school in California. PhD Thesis, University of San Francisco. ProQuest Dissertations and Theses.

Matsuda A and Duran CS (2013) Problematizing the construction of Americans as monolingual English speakers. In: Ramanathan V (ed) Language policy, pedagogic practices: Rights, access, citizenship Bristol, England: Multilingual Matters, pp. 35-51.

May H and Perna L (2011) A longitudinal analysis of student and school diversity in the International Baccalaureate (IB) Diploma Program in the U.S. Paper presented at the Annual Meeting of the American Educational Research Association. Retrieved from http://www.cpre.org/sites/default/files/meetingpaper/ 1373_aera2011ib.pdf

May S (2009) The visibility of Deweyan inquiry in an International Baccalaureate elementary school. Ph.D. Thesis, Retrieved from ProQuest Dissertations \& Theses database.

McGroarty M (2010) Language and ideologies. In Hornberger N and McKay S (2010) Sociolinguistics and language education. Tonawanda, NY: Multilingual Matters, pp. 338.

Mills H (2013) The impact of U.S. educational policy on the implementation of the IB Primary Years Programme: A case study of an urban, low-income public school. Retrieved from http://www.ibo.org/contentassets/4ccc99665bc04f3686957 ee197c13855/finalexecutivesummary-mills.pdf 
Motha S (2014) Race, empire, and English language teaching: Creating responsible and ethical anti-racist practice. NY: Teachers College Press.

Murphy E (2003) Monolingual international schools and the young non-Englishspeaking child. Journal of Research in International Education, 2(1): 25-45.

Murphy E (2011) Welcoming linguistic diversity in early childhood classrooms:

Learning from international schools. Tonawanda, NY: Multilingual Matters.

Pennycook A (2001) Critical applied linguistics: A critical introduction. Mahwah, NJ: Erlbaum.

Pennycook A (2004) Performativity and language studies. Critical Inquiry in Language Studies, 1(1): 1-19.

Phillipson R (1992) Linguistic imperialism. Oxford: Oxford University Press.

Parker WC (2011) International education in US Public Schools. Globalisation, Societies and Education, 9(3-4): 487-501. doi: 10.1080/14767724.2011.605330

Quaynor LJ (2012) Refugee students in global schools, constructing citizenship: A comparative case study of sixth grade classrooms in two public IB schools. PhD Thesis, Emory University. ProQuest Dissertations and Theses.

Quaynor L (2015) Connections and contradictions in teacher practices for preparing globally minded citizens in two IB public schools. Teachers College Record, 117 (9): 138. Retrieved from http://www.tcrecord.org

Resnik J (2012) The denationalization of education and the expansion of the International Baccalaureate. Comparative Education Review, 56(2): 248-269.

Resnik J (2009) Multicultural education — Good for business but not for the state? The IB curriculum and global capitalism. British Journal of Educational Studies, 57(3): 217244. 
Schieffelin B, Woolard K and Kroskrity P (eds) (1998) Language ideologies:

Practice and theory. New York: Oxford University Press.

Sears C (2015) Second language students in English-medium classrooms: A guide for teachers in international schools. Bristol, UK: Multilingual Matters. Accessed via Kindle Fire HD ( $3^{\text {rd }}$ Generation).

Scott J (2011) Writing and implementing a language policy in the primary section of a linguistically diverse school. In Murphy E (ed) Welcoming linguistic diversity in early childhood classrooms: Learning from International Schools. Tonawanda, NY: Multilingual Matters, pp. 196-203

Silverstein M (1998) The uses and utility of ideology. In Schiefflin B, Woolard K and Kroskrity P (eds) Language ideologies: Practice and Theory. Oxford: Oxford University Press, pp. 123-145.

Siskin L, Weistein M and Sperling R (2010) To be IB. Creating support structures and services for Title I high schools implementing the International Baccalaureate Programme. NYU Wagner Research Paper No. 2011-11.

Skutnabb-Kangas T and Phillipson R (1995) Linguistic human rights: overcoming linguistic discrimination. Berlin, Germany: Mouton de Gruyter.

Spitzer N (2012) The Story Of Woody Guthrie's 'This Land Is Your Land'. NPR. Retrieved from http://www.npr.org/2000/07/03/1076186/this-land-is-your-land Stillisano JR, Waxman HC, Hostrup J and Rollins KB (2011) Case studies of eight Texas schools implementing International Baccalaureate programs. Journal of Ethnographic \& Qualitative Research, 5: 171-185.

Suárez-Orozco C \& Suárez-Orozco M (2008) Learning in a new land: Immigrant students in American society. Cambridge, MA: Belknap Press of Harvard University Press. 
Suárez-Orozco C, Yoshikawa H and Tseng V (2015) Intersecting inequalities:

Research to reduce inequality for immigrant-origin children and youth. William T. Grant Foundation. Retrieved from http://blog.wtgrantfoundation.org/post/ 111903703827/ intersecting-inequalities-research-to-reduce

Tan L and Bibby Y (2010) IB PYP and MYP student performance on the International Schools' Assessment (ISA). Melbourne: Australian Council for Educational Research.

Twigg VV (2010) Teachers' practices, values and beliefs for successful inquirybased teaching in the International Baccalaureate Primary Years Programme. Journal of Research in International Education, 9(1): 40-65. doi: $10.1177 / 1475240909356947$

van Oord L (2007) To westernize the nations? An analysis of the International Baccalaureate's philosophy of education. Cambridge Journal of Education, 37(3): 375390. doi: $10.1080 / 03057640701546680$

Van Vooren C, Lai C, Ledger S, Bueno Villaverde A and Steffen V (2013) Additional language teaching and learning in the International Baccalaureate Primary Years Program schools. The Hague, NL: International Baccalaureate Organization. Retrieved from http://www.ibo.org/globalassets/publications/ib-research/additionallanguagefinal report.pdf

Visser A (2010) International Education in a national context: Introducing the International Baccalaureate Middle Years Programme in Dutch public schools. Journal of Research in International Education, 9(2): 141-152.

Woolard K and Schieffelin B (1994) Language ideology. Annual Review of Anthropology, 23: 55-82. 